\title{
Proteomic analysis of Metarhizium anisopliae secretion in the presence of the insect pest Callosobruchus maculatus
}

\begin{abstract}
Correspondence
Octávio L. Franco

ocfranco@pos.ucb.br

or

ocfranco@gmail.com
\end{abstract}

Received 3 August 2008

Revised 2 September 2008

Accepted 3 September 2008

\author{
André M. Murad, ${ }^{1}$ Eliane F. Noronha, ${ }^{1}$ Robert N. G. Miller, ${ }^{1}$ Fabio T. Costa, ${ }^{1}$ \\ Caroline D. Pereira, ${ }^{1}$ Ângela Mehta, ${ }^{2}$ Ruy A. Caldas ${ }^{1}$ and \\ Octávio L. Franco ${ }^{1,3}$ \\ ${ }^{1}$ Centro de Análises Proteômicas e Bioquímicas, Pós-Graduação em Ciências Genômicas e \\ Biotecnologia UCB, Brasília-DF, Brazil \\ ${ }^{2}$ Embrapa Recursos Genéticos e Biotecnologia, Brasília-DF, Brazil \\ ${ }^{3}$ Universidade Federal de Juiz de Fora, Juiz de Fora-MG, Brazil
}

\section{INTRODUCTION}

Callosobruchus maculatus is the main pest of cowpea (Vigna unguiculata), a common smallholder crop in Latin America and Africa (Delincee et al., 1998). During its larval stage, this weevil feeds on cotyledon material, causing significant economic losses through reduced seed quality and quantity (Credland et al., 1986). Control of $C$. maculatus currently relies upon application of chemical insecticides, biological control with bacteria, protozoa, nematodes, viruses and fungi (Kaya \& Gaugler, 1993; Legner, 1995; Becker, 1998; Scholte et al., 2004; Jackai \& Adalla, 1997; Galvan et al., 2006), and post-harvest treatment with ionizing radiation (Delincee et al., 1998). In recent years, the applicability of entomopathogenic

\footnotetext{
Abbreviation: PMF, peptide mass fingerprinting.

Supplementary data are available with the online version of this paper: two supplementary figures, showing Bradford analysis of protein concentration of fungal secretions and the $M$. anisopliae growth curve in the presence and absence of dehydrated $C$. maculatus, and a supplementary table presenting in silico evidence of the presence of secretion signal peptide in proteins secreted by $M$. anisopliae in response to the presence of $C$. maculatus adult insects.
}

fungi has been examined for biological control of coleopteran pests (Adane et al., 1996; Rice \& Cogburn, 1999; Bourassa et al., 2001; Kassa et al., 2002). For example, strains of Metarhizium anisopliae from diverse geographical origins have been characterized according to their virulence against storage Bruchidae pests of maize, beans, rice and other agricultural crops (Cherry et al., 2005; Murad et al., 2006, 2007). These fungi secrete hydrolytic enzymes involved in insect attack, and offer potential for development of bioinsecticides and/or construction of pestresistant genetically modified plants (Murad et al., 2006, 2007). In a previous study, we screened $10 \mathrm{M}$. anisopliae isolates for virulence against $C$. maculatus, and performed enzymic and 2D gel electrophoretic analyses of fungal secretions in the absence and presence of dehydrated $C$. maculatus (Murad et al., 2006). The results indicated that M. anisopliae strain CG34 has potential as a source of proteins for control of $C$. maculatus. Other authors have also utilized proteomic approaches in fungi for discovery of novel compounds with biological control properties. For example, Grinyer et al. (2004) characterized secretions in Trichoderma atroviride (formerly Trichoderma harzianum). This mycopathogenic fungus inhibits growth of diverse 
phytopathogens, offering an alternative to traditional chemical control. A novel aspartic proteinase has been identified in $T$. atroviride secretions, induced by cell wall material from the pathogen Rhizoctonia solani (Suarez et al., 2005). Hydrolytic enzymes have also been detected in $T$. atroviride, active against $R$. solani (Grinyer et al., 2005). Two-dimensional gels have also been utilized to identify molecular mechanisms involved in degradation of exoskeleton material in the grasshopper Melanoplus sanguinipes, using proteinases secreted from $M$. anisopliae and Beauveria bassiana (Bidochka \& Khachatourians, 1994). Proteomic approaches have also been applied to elucidate physiological processes in Aspergillus fumigatus (Carberry et al., 2006). This fungus synthesizes approximately 250 proteins, of which 110 are related to energy metabolism, with constitutive expression in carbohydrate uptake and metabolism. A 2D LC-MS/MS (liquid chromatography mass spectrometry/mass spectrometry) approach has also been utilized to analyse protein expression in Saccharomyces cerevisiae during responses to nutritional stress (Kolkman et al., 2006).

Based upon such studies, we continued the work described previously (Murad et al., 2006), analysing secretions in the virulent $M$. anisopliae strain CG34. Important enzymes involved in fungal carbohydrate/nitrogen metabolism were identified, providing novel insights into the physiology of insect host colonization by $M$. anisopliae. These offer potential for development of new tools for improved crop protection to insect pests.

\section{METHODS}

Cowpea weevil colonies. C. maculatus colonies were maintained in flasks which contained cowpea seeds and incubated at $28{ }^{\circ} \mathrm{C}$ with 60 $70 \%$ relative humidity. Secretion induction in M. anisopliae was carried out using adult weevils removed from colonies $24 \mathrm{~h}$ after oviposition. Insects were dehydrated at $49{ }^{\circ} \mathrm{C}$ for $48 \mathrm{~h}$ and macerated.

Production of the secretome. M. anisopliae strain CG34 was obtained from the Entomopathogenic Fungal Collection, Embrapa Recursos Genéticos e Biotecnologia (Brazil). This strain was previously determined by our group as the most virulent against $C$. maculatus (Murad et al., 2006). Following initial incubation for 10 days at $28{ }^{\circ} \mathrm{C}$ on potato dextrose agar $(10 \%$ potato, $0.1 \%$ Dglucose and $2.5 \%$ agar at $\mathrm{pH} 7.0)$, a conidial spore suspension $\left(10^{7}\right.$ spores $\mathrm{ml}^{-1}$ ) was prepared and inoculated into TM medium, containing $0.1 \%$ bactopeptone, $0.03 \%$ urea, $0.2 \% \mathrm{KH}_{2} \mathrm{PO}_{4}, 1.4 \%$ $\left(\mathrm{NH}_{4}\right)_{2} \mathrm{SO}_{4}, 0.03 \% \mathrm{MgSO}_{4} .7 \mathrm{H}_{2} \mathrm{O}, 0.3 \%$ glucose, and $\mathrm{FeCl}_{3}$ as trace element. After 3 days incubation at $38{ }^{\circ} \mathrm{C}$ and 130 r.p.m., mycelia were washed several times with sterile distilled $\mathrm{H}_{2} \mathrm{O}$ and transferred to an induction medium comprising minimal medium $\left(0.2 \% \mathrm{KH}_{2} \mathrm{PO}_{4}\right.$, $0.03 \% \mathrm{MgSO}_{4}, 1.4 \%\left(\mathrm{NH}_{4}\right)_{2} \mathrm{SO}_{4}$ and $\mathrm{FeCl}_{3}$ as trace element), together with $0.5 \%$ dehydrated C. maculatus. Mycelia were reincubated for 3 days with agitation at $29^{\circ} \mathrm{C}$ and at 130 r.p.m. Culture broth was filtered through $0.3 \mu \mathrm{m}$ Millipore filters, dialysed against water with a $1.0 \mathrm{kDa}$ cutoff at $4{ }^{\circ} \mathrm{C}$, lyophilized and stored at $-80{ }^{\circ} \mathrm{C}$. In evaluation of fungal growth conditions, mycelial dry weight was measured, and average $\mathrm{pH}$ values determined. A growth time-course was also determined, with secretions collected during the exponential phase only (see Supplementary Fig. S1, available with the online version of this paper). Viable cells were counted using a
Neubauer chamber, in order to guarantee that experiments were not contaminated with intracellular proteins following lysis. As a negative control, M. anisopliae was also grown in the absence of dehydrated insects, using otherwise identical growth conditions.

Quantification of protein secretion. The Bradford method (Bradford, 1976) and the fluorescent Qubit kit (Invitrogen) were used for protein quantification. In the first method, $1.0 \mathrm{ml}$ Bradford reagent (100 mg Coomassie brilliant blue, $50 \mathrm{ml} 95 \%$ ethanol and $100 \mathrm{ml} 85 \%$ phosphoric acid) was added to a $100 \mu \mathrm{l}$ sample. Distilled water was used as a negative control. $\mathrm{OD}_{595}$ was measured by spectrophotometry, using BSA to construct the standard curve. The second method was conducted according to the manufacturer's instructions.

Gel electrophoresis analyses. Isoelectric focusing and molecular mass separation were conducted according to the protocol of Gorg et al. (1988), using $13 \mathrm{~cm}$ immobilized $\mathrm{pH}$ gradient (IPG) strips with a $\mathrm{pH}$ range of 3-11 and a Multiphor II electrophoresis system (GE Healthcare). A $2000 \mu \mathrm{g}$ portion of each sample was resuspended in $0.005 \mathrm{M}$ Tris/EDTA buffer containing $1 \mathrm{mM}$ PMSF and $1 \mathrm{mM}$ E-64 protease inhibitor, divided into four equal volumes and further precipitated using a 2D Clean-Up kit (GE HealthCare). Precipitate containing $500 \mu \mathrm{g}$ total protein was resuspended in a $250 \mu \mathrm{l}$ solution

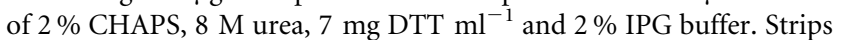
were hydrated in this solution for $16 \mathrm{~h}$. Isoelectric focusing was performed in gradient mode for $30 \mathrm{~min}$ at $500 \mathrm{~V}, 30 \mathrm{~min}$ at $1000 \mathrm{~V}$, $90 \mathrm{~min}$ at $35000 \mathrm{~V}$ and $380 \mathrm{~min}$ at $3500 \mathrm{~V}$, at $2 \mathrm{~mA}$ and $5 \mathrm{~W}$. After the first dimension, strips were equilibrated in a solution of $6 \mathrm{M}$ urea, $1 \%$ DTT and $2 \%$ SDS for $15 \mathrm{~min}$ and then applied to gels. Mini-gel and second-dimension separation were performed in $18 \times 16 \times$ $0.1 \mathrm{~cm}$ SDS-PAGE $12.5 \%$ gels, as described by Laemmli (1970), with bromophenol blue used as tracking dye. Electrophoresis was conducted on a Hoefer system (GE HealthCare) at $250 \mathrm{~V}, 40 \mathrm{~mA}$ and $10 \mathrm{~W}$ for $5 \mathrm{~h}$. Gels were silver stained and repeated in triplicate. The broad-range pI marker (GE Healthcare) was also used for pI identification on gels. Gels were evaluated in technical triplicate and biological duplicate.

Gels were digitzed using an HP Scanjet model 8290 scanner and further analysed with Bionumerics software v. 4.5 (Applied Maths). Calibration with a grey scale was necessary to transform grey levels into values for each pixel of the gel picture. This was conducted using a calibration curve. All gel images were analysed as .tif files. The six gel images were placed in one folder and the wizard detection method proposed by the software was used for spot detection. Automatically detected spots were manually checked, with manual addition or removal according to size $(>0.2 \mathrm{~cm})$, shape (circular) and density $\left(>2\right.$ pixels $\left.\mathrm{cm}^{-1}\right)$. Following the detection procedure, a normalization step was conducted to assign common protein identities to identical spots derived from different images. For this procedure, a reference gel was constructed, using automatic matching options. For each sample, when a protein was detected in all gel images, this protein was automatically added to the reference gel.

Protein digestion. All spots were excised from gels using a scalpel and placed into $1.5 \mu \mathrm{l}$ microtubes. A protein in-gel digestion with Gold sequencing-grade trypsin (Promega) was conducted following the procedure of Shevchenko et al. (1996). A $300 \mu \mathrm{l}$ volume of $100 \%$ acetonitrile was added to tubes for $5 \mathrm{~min}$. Supernatant was removed and spots were dried in a SpeedVac for $5 \mathrm{~min}$. Samples were incubated for $60 \mathrm{~min}$ at $56{ }^{\circ} \mathrm{C}$ in a solution containing $50 \mu 10 \mathrm{mM}$ DTT and $100 \mathrm{mM} \mathrm{NH} \mathrm{HCO}_{3}$. The solution was replaced with $50 \mu \mathrm{l}$ $55 \mathrm{mM}$ iodoacetamide and $100 \mathrm{mM} \mathrm{NH} \mathrm{NHCO}_{3}$ and incubated in darkness for $45 \mathrm{~min}$. Spots were rinsed twice with MilliQ water (Millipore) for $10 \mathrm{~min}$, and exposed to $100 \mu \mathrm{l} 100 \%$ acetonitrile for $5 \mathrm{~min}$. Excess acetonitrile was removed and again spots were dried on 
a SpeedVac for $5 \mathrm{~min}$. Protein digestion was carried out using $650 \mathrm{ng}$ trypsin diluted in $50 \mu \mathrm{l} 50 \mathrm{mM} \mathrm{NH} \mathrm{HCO}_{3}$ and $6 \mathrm{mM} \mathrm{CaCl}_{2}$, with overnight incubation at $37{ }^{\circ} \mathrm{C}$. The supernatant was used for mass spectrometry analysis.

Mass spectrometry. The peptides derived from tryptic digestion were analysed as described by Henzel et al. (1993), using an UltraFlex II MALDI-TOF/TOF instrument (Bruker Daltonics). Each sample $(2 \mu \mathrm{l})$ was mixed in $6 \mu \mathrm{l} 0.1 \% \alpha$-cyano-4-hydroxycinnamic acid, $0.1 \%$ trifluoroacetic acid and acetonitrile $(1: 1)$. A volume of $0.5 \mu \mathrm{l}$ was applied to a MALDI plate and dried at room temperature. Spectrometry was operated in linear mode for MS acquisition and reflected mode for MS/MS acquisitions using modulated power with 200 random shoots. Data were saved in standard Bruker's software format.

Protein identification. Spots were identified using peptide mass fingerprinting (PMF) and de novo sequencing. The mass list for each sample was analysed using the program MASCOT v2.1.0 (Matrix Science; http://www.matrixscience.com), assuming one mis-cleavage, carboxymethylation and methionine oxidation as modification. The lists of masses were compared against the non-redundant NCBI database. Results were evaluated by comparing the molecular mass and $\mathrm{pI}$ of the most scored hit with data observed in 2D gels. De novo sequencing was conducted manually, subtracting the masses from $y$ series and comparing them to amino acid masses. Sequences were then compared to the Swiss-Prot database (http://www.expasy.org) using the MPSrch tool from the European Institute of Bioinformatics (EBI). Only protein hits with molecular mass and pI values similar to those found on gels, together with coverage, similarity and tryptic digestion pattern, were considered for identification. Protein spots with lower scores were considered unidentified and were discarded.

\section{RESULTS AND DISCUSSION}

SDS-PAGE was carried out to evaluate $M$. anisopliae secretions in response to the presence of $C$. maculatus insects (Fig. 1). Induced and non-induced secretions

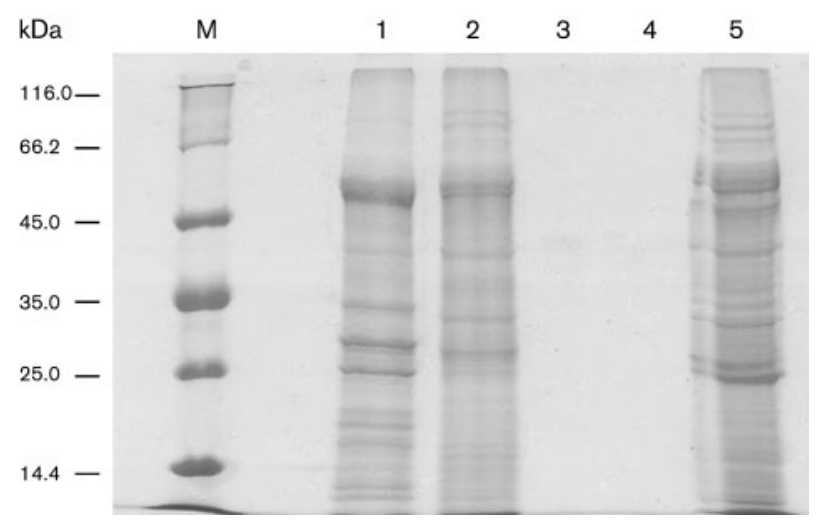

Fig. 1. SDS-PAGE analyses of $M$. anisopliae secretion in the presence (induced, lane 1) and in the absence (non-induced, lane 2) of C. maculatus insects. Fresh medium (lane 3) and medium containing only insects (lane 4) were used as negative controls. $M$. anisopliae was also transferred to fresh medium after induction and evaluated after $48 \mathrm{~h}$ (lane 5). Each sample was evaluated at a standard concentration of $30 \mu \mathrm{g} \mathrm{ml}^{-1}$. M, molecular mass markers. showed clear differences in protein patterns. Fresh minimal medium and medium lacking insect exoskeleton, used as a negative control, showed no protein bands. When $M$. anisopliae grown in the presence of insects was transferred to fresh minimal medium without insect shells (last lane, Fig. 1), a clear modification in secretion patterns was observed. Protein secretion was similar to that observed under non-induced conditions, which supports the conclusion that certain proteins are expressed in response to the presence of insects. However, a number of proteins detected in $M$. anisopliae on minimal medium without insect shells were similar to proteins observed on induced medium. Two explanations may help to elucidate such findings. Firstly, the fungus may continue to express proteins induced by the presence of insect shells for some time after transfer to fresh medium. A second hypothesis is that following transfer, different proteins with similar molecular masses, not observed in non-induced and induced media, are also expressed in response to reduction in carbon and nitrogen sources. Similar data were previously observed by Hess et al. (2006) in yeasts subjected to ammonia and potassium limitation. Following growth of $M$. anisopliae strain CG34 on the induction medium containing dehydrated C. maculatus, as well as in an identical broth lacking insects, 2D gels were produced for characterization of protein expression (Fig. 2). Secretions were collected during the exponential phase to reduce cell lysis, senescence and autophagy (see Supplementary Figs S1 and S2, available with the online version of this paper). Microscopic analyses showed that approximately $98 \%$ of fungal cells were intact, with entire hyphal structures (data not shown). Each gel was loaded with $500 \mu \mathrm{g}$ total secreted proteins for both treatments, representing a total mycelial mass of $1.87 \mathrm{~g}$ in induced conditions and $10.15 \mathrm{~g}$ in non-induced conditions. Whether induced or non-induced, M. anisopliae strain CG34 expressed more proteins in the current study than observed previously (Murad et al., 2006). Marked differences in protein yield may reflect utilization of a higher protein concentration in combination with a thinner gel $(1.0 \mathrm{~mm}$ rather than $1.5 \mathrm{~mm})$ and a $2 \mathrm{D}$ Clean-Up kit to enhance protein yield. In total, 30 additional spots were observed on $1.0 \mathrm{~mm}$ gels with different pIs and molecular masses (Fig. 2). Moreover, correlation curves of $2 \mathrm{DE}$ calculated with the Bionumerics software Image analysis superposition improved reliability. These curves showed that biological replicates were extremely reproducible, indicating a correlation rate of 0.92 (data not shown). Moreover, when 2D gels from technical replicates were compared, the correlation rate increased to 0.95 (data not shown). By contrast, when induced and non-induced gels were compared in silico, only a correlation rate below 0.12 was obtained, suggesting that the gels were extremely different and, therefore, not comparable.

Spots marked on the induced gel (Fig. 2) were excised and, following gel trypsin digestion, peptides were identified on the basis of mass spectrometry (Table 1), $\mathrm{pI}$ and relative 


\section{Non-induced}

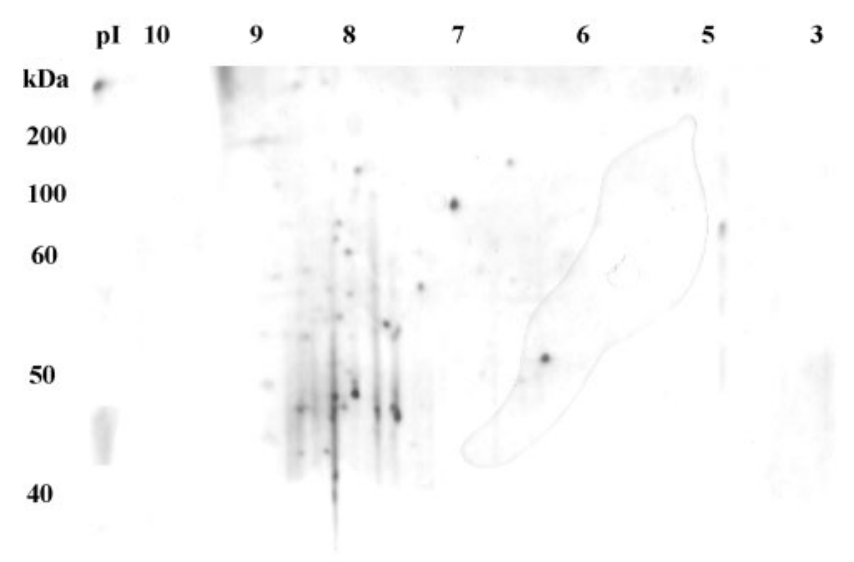

30

20

\section{Induced}

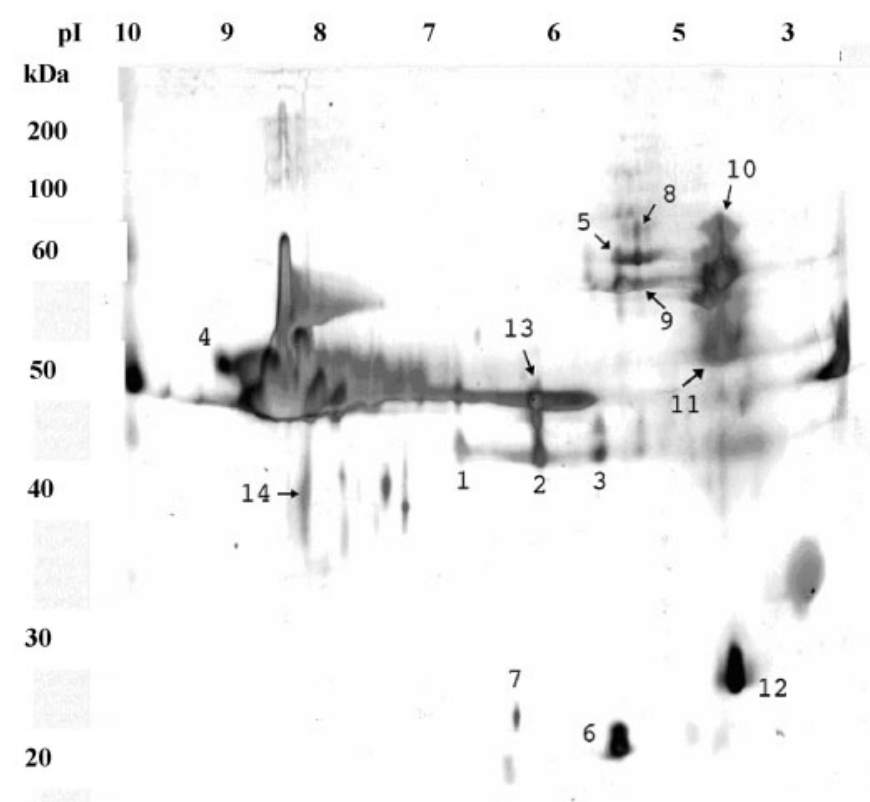

Fig. 2. Two-dimensional electrophoreses of $M$. anisopliae secretion in the presence (induced) and in the absence (noninduced) of C. maculatus insects. Numbers and arrows indicate analysed and identified spots. A broad-range pl marker from GE Healthcare and a theoretical molecular mass obtained from MS data were used. Gels were silver stained. 2D gels were performed in triplicate, with a correlation value higher than 0.9 . Gels were evaluated in technical triplicate and biological duplicate.

Table 1. Proteins identified from M. anisopliae secretions

PMF was conducted using the software Mascot. MPSrch score, pI and molecular mass were used for identification. De novo sequences were compared to the Swiss-Prot database using MPSrch from the European Bioinformatics Institute. MPSrch score, pI and molecular mass were also used for identification.

\begin{tabular}{|c|c|c|c|c|c|c|c|}
\hline Spot & $\begin{array}{l}\text { Cover } \\
(\%)\end{array}$ & Score & $\begin{array}{l}\text { Theoretical } \\
\text { mass (Da) }\end{array}$ & $\begin{array}{c}\text { Theoretical } \\
\text { pI }\end{array}$ & $\begin{array}{c}\text { Hits } \\
\text { access code }\end{array}$ & Identification & Similarity \\
\hline 1 & 15 & 54 & 24839 & 5.39 & XP_749174 & PMF & $\begin{array}{l}\text { Acetyltransferase, GNAT family (Aspergillus } \\
\text { fumigatus) }\end{array}$ \\
\hline 2 & 2 & 47 & 43725 & 6.65 & ZP_01313438 & KGYVYTR & Putative methionine $\gamma$-lyase \\
\hline 3 & 21 & 44 & 43533 & 9.57 & gil 85090383 & PMF & ATPase (Desulfuromonas acetoxidans) \\
\hline 4 & 10 & 45 & 51382 & 8.67 & NP_015228 & PMF & $\begin{array}{l}\text { Mitochondrial tyrosyl-tRNA synthetase } \\
\text { (Saccharomyces cerevisiae) }\end{array}$ \\
\hline 5 & 16 & 34 & 57243 & 5.99 & CAB63907.1 & PMF & $\begin{array}{l}\text { Subtilisin-like protease PR1H (Metarhizium } \\
\text { anisopliae) }\end{array}$ \\
\hline 6 & 41 & 51 & 14535 & 5.12 & Q4R5J1 & PMF & Dehydrogenase \\
\hline 7 & 37 & 44 & 16057 & 7.75 & NP_084164.1 & PMF & Zinc finger protein 142 (Mus musculus) \\
\hline 8 & 5 & 40 & 55108 & 4.93 & XP_572174.1 & PMF & $\alpha$-Amylase (Cryptococcus neoformans) \\
\hline 9 & 10 & 46 & 51760 & 4.42 & AA_119890705 & PMF & $\begin{array}{l}\text { Regulation protein of Tyl (Saccharomyces } \\
\text { cerevisiae) }\end{array}$ \\
\hline 13 & 2 & 37 & 48093 & 6.84 & Q2P5Z4_XANOM & AFTYTR & Putative aminotransferase \\
\hline 14 & 4 & 56 & 37017 & 6.73 & A1ZIA1_9SPHI & KQVTYHVYYINR & Oxidoreductase \\
\hline
\end{tabular}


mass observed on gels. Our data, in addition to previous reports (Murad et al., 2006; Kolkman et al., 2006; Lomako et al., 2004; Lesage \& Bussey, 2006), indicate a clear nutrient uptake strategy, suggesting metabolic pathways involved in degradation of compounds from liquid culture. Fig. 3 illustrates the probable chitin degradation cycle for strain CG34. Following chitin hydrolysis by endo/exo chitinases (Murad et al., 2006; Kang et al., 1999) (EC 3.2.1.14), as detected by enzyme assays in our previous study (Murad et al., 2006), the synthesized $N$-acetyl-Dglucosamine may be phosphorylated by an $N$-acetyl-Dglucosamine kinase (spot 10). Chitin may be deacetylated by a chitin deacetylase (Nahar et al., 2004) (EC 3.5.1.41), and D-glucosamine units may be acetylated once again by a

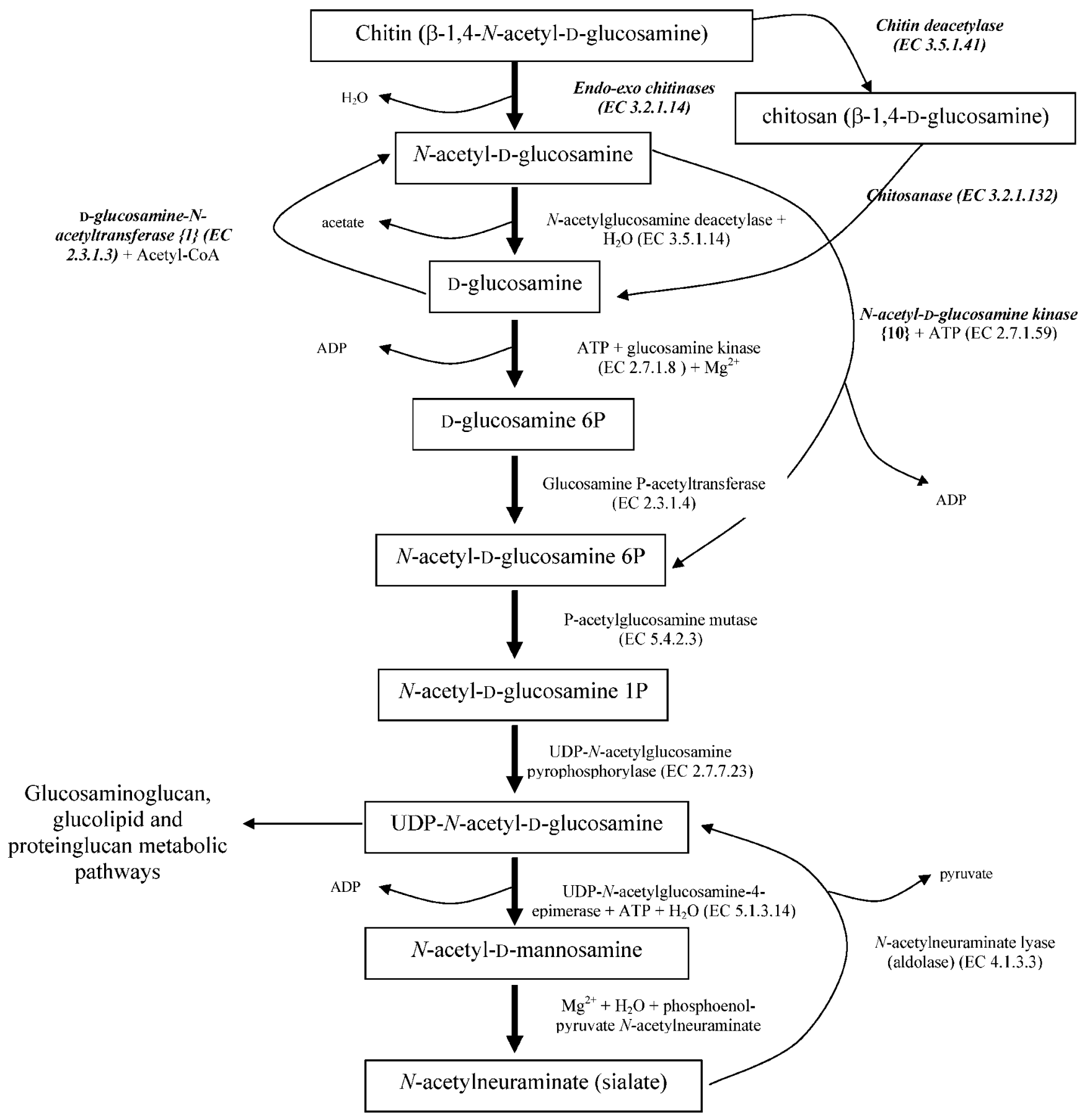

Fig. 3. Chitin degradation pathway in M. anisopliae. Bold italic type indicates enzymes described in fungi in this report or by other authors. Numbers in \{\} indicate the identified spots from Fig. 2 and further described in Table 1. 
D-glucosamine $\mathrm{N}$-acetyltransferase (spot 1) (EC 2.3.1.3) followed by a further phosphorylation by $\mathrm{N}$-acetyl-Dglucosamine kinase (spot 10). Lesage \& Bussey (2006) reviewed cell wall assembly mechanisms in S. cerevisiae, another ascomycete, reporting that several enzymes are necessary, including chitin deacetylases. Chitosan, which is a deacetylated derivative of chitin, is much more water soluble, facilitating adsorption of this compound by fungal cell walls. Although it is not clear how prevalent chitosan is among fungi, appearing mainly in zygomycetes, this polymer has now been reported in cell walls in ascomycetes. For example, chitosan has been detected during both sporulation, in the case of $S$. cerevisiae, and vegetative growth, in the case of Cryptococcus neoformans (Banks et al., 2005).

The phosphorylated product $\mathrm{N}$-acetyl-D-glucosamine 6phosphate is important for synthesis of UDP- $N$-acetyl-Dglucosamine and later conversion by other metabolic pathways to UDP-glucose. This may then serve for synthesis of glycogen, as previously described in fungi (Lomako et al., 2004). N-Acetyl-D-glucosamine-6-phosphate may be metabolized into UDP- $N$-acetyl-D-glucosamine, following the described metabolic pathway (Fig. 3). Aldolase may transform $\mathrm{N}$-acetyl-neuraminate into UDP$\mathrm{N}$-acetyl-D-glucosamine, producing pyruvate. Furthermore, UDP- $N$-acetyl-D-glucosamine is also an important substrate in the dolichol metabolic pathway, which results in the production of glycosaminoglycans, glycolipids and protein glucans. These molecules are used for energy storage and in cell walls (Sorensen et al., 2003). Assigning potential roles to our identified proteins in metabolic pathways, we propose that UDP- $N$-acetyl-D-glucosamine is produced within the cell following the metabolism of $\mathrm{N}$-acetyl-D-glucosamine-6-phosphate, with products utilized for energy metabolism. In addition, D-glucosamine can be transformed into glucose and used by fungi to construct their cell walls using $\beta-1,3 / 1,6$ glucose polymers, as described in S. cerevisiae (Lesage \& Bussey, 2006). Moreover, Kolkman et al. (2006) used LC-MS/MS proteomic techniques to characterize differentially induced protein expression in $S$. cerevisiae following starvation. Their work showed that during carbon source limitation $S$. cerevisiae expresses genes that code for enzymes involved in carbohydrate metabolism, cellular machinery, fatty acid metabolism, glycolysis, oxidative phosphorylation and enzymes of the citric acid cycle. Our work indicates that $M$. anisopliae produced only enzymes involved in carbohydrate metabolism, but which may have an analogous metabolism in nutritional stress responses.

Proteolytic enzymes are also produced by $M$. anisopliae during host colonization (St Leger et al., 1997, 1986). Our data (Table 1) showed similarities with previous 2D identification of proteinases (Bidochka \& Khachatourians, 1994), where degrading enzymes active against grasshopper (Melanoplus sanguinipes) cuticle were characterized from the entomopathogens $M$. anisopliae and $B$. bassiana. Several reports (St Leger et al., 1987, 1994) have also described several trypsins and subtilisins from M. anisopliae. Together with our results, these findings make it clear that these enzymes are important for insect colonization by entomopathogens. It is widely known that numerous fungi utilize a nitrogen metabolism process different from that of plants and bacteria (Kneip et al., 2007). Fungi are unable to extract nitrogen from the atmosphere, such activity being exclusive to bacteria (Kneip et al., 2007). However, fungi are able to process nitrogen from other compounds: primarily from glutamine, glutamate and ammonium; and secondly from nitrite, nitrate, amino acids, purines, acetamide and acrylamide (Marzluf, 1981). For all these compounds, the synthesis of nitrogen-regulated enzymes can only occur if nitrogen catabolite repression (namely ammonium repression) is lifted. In other words, the need for nitrogen catabolization can be reduced by factors such as the presence of ammonium in the medium (Marzluf, 1981). The genetics of these characteristics were studied in Aspergillus nidulans and Neurospora crassa, and genes controlling the production of nitrite/nitrate reductase were identified (Marzluf, 1981). On this basis, given the high proteolytic activities seen in CG34 (Murad et al., 2006) and the identified proteins, the metabolic pathway depicted in Fig. 4 is proposed. Proteins may be hydrolysed by a trypsin (St Leger et al., 1996) (spot 12, Fig. 2) and by one subtilisin (St Leger et al., 1994) (spot 5), producing free essential amino acids and small peptides that can be further assimilated. A methionine gamma lyase (spot 2) and amidohydrolase (spot 11) hydrolyse the $-\mathrm{NH}_{2}$ groups found on N-termini and side chains of basic residues. $\mathrm{NH}_{3}$ becomes a substrate for ammonia monooxygenase, which results in $\mathrm{NH}_{2} \mathrm{OH}$. This compound is then oxidized by hydroxylamine dehydrogenase to nitrite $\left(\mathrm{NO}_{2}\right)$, which is converted by nitrite oxidoreductase (spot 14) to nitrate $\left(\mathrm{NO}_{3}^{-}\right)$. A similar process has been described by Marzluf (1981) in A. nidulans and N. crassa. This is an important mechanism for reducing high ammonium levels, given that this compound is toxic to organisms such as S. cerevisiae (Hess et al., 2006). Aminotransferase was another important enzyme identified in our study (spot 13). There are many types of aminotransferases. In our case, we appear to have identified both a D-alanine aminotransferase (EC 2.6.1.21), catalysing the reaction of $\mathrm{D}$-alanine +2 -oxoglutarate to pyruvate $+\mathrm{D}$-glutamate, as well as an aspartate aminotransferase (EC 2.6.1.1), which catalyses the reaction of L-aspartate +2 -oxoglutarate to oxaloacetate $+\mathrm{L}$-glutamate, as previously found in S. cerevisiae (Cronin et al., 1991). Kolkman et al. (2006) also showed that under limited nitrogen conditions, S. cerevisiae expresses genes responsible for amino acid metabolism, glycolysis, glycogen metabolism and several proteolytic enzymes, which also could be observed in M. anisopliae secretions (Fig. 4).

The identification of an $\alpha$-amylase (spot 8, Table 1) was a surprising result, considering that $M$. anisopliae showed only low $\alpha$-amylolytic activity in the presence of cowpea weevil (Murad et al., 2006). In fact, this starch-hydrolysing enzyme was not expected to be identified, as insects do not 


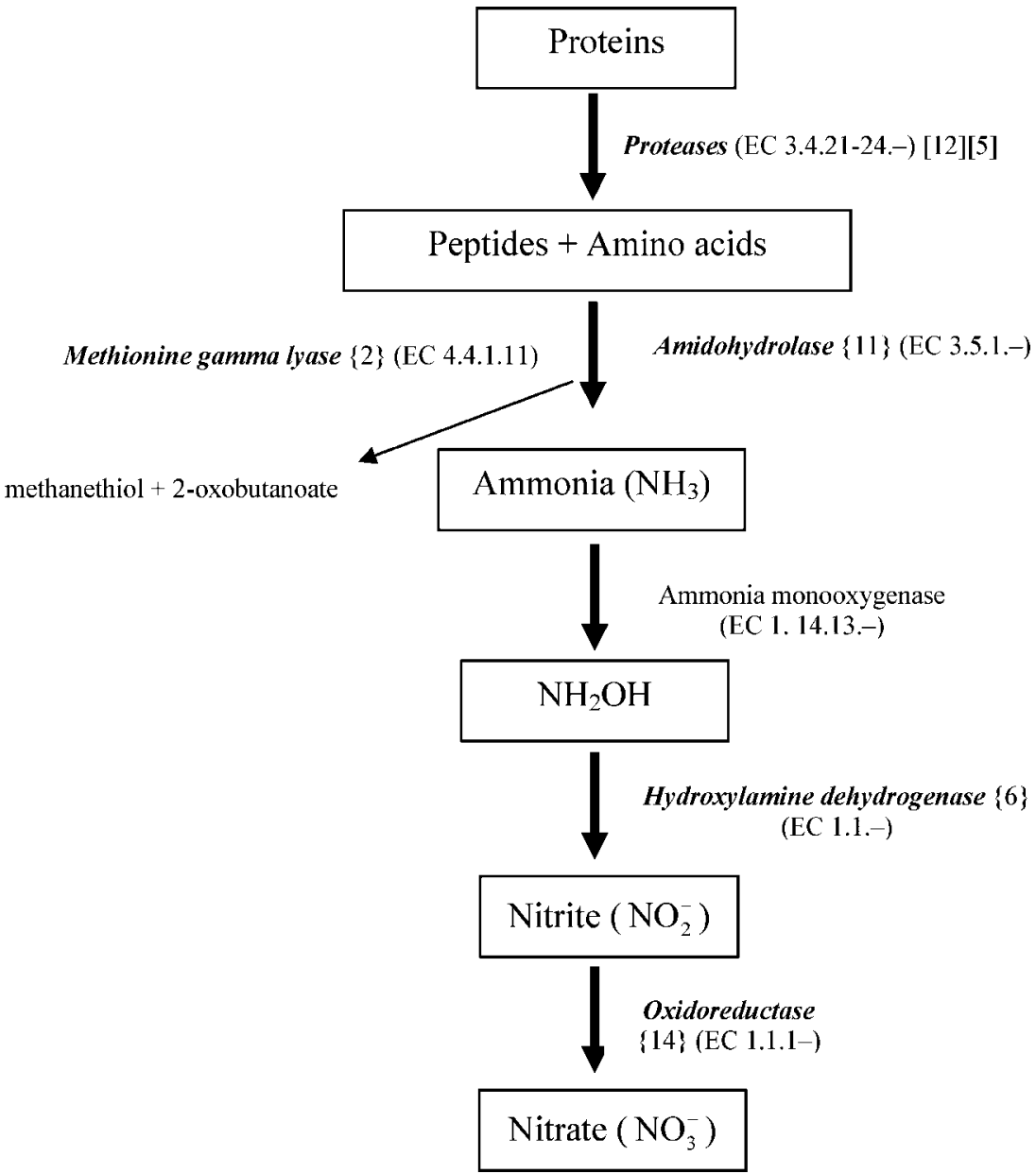

Fig. 4. Protein and ammonia degradation pathway in $M$. anisopliae. Bold italic type indicates enzymes described in fungi in this report or by other authors. Numbers in \{\} indicate the identified spots from Fig. 2 and further described in Table 1. synthesize starch. We propose that at some point CG34 identified carbohydrate-binding enzymes as necessary for metabolism of C. maculatus shells, transcribing and secreting several of these into the culture media. The spot in question (spot 8, Fig. 2) showed only a low intensity, supporting this theory. Some additional proteins were also identified, although their possible mechanism of action in nutrient uptake remains unclear. Among these were an ATPase (spot 3, Fig. 2 and Table 1), tRNA synthetase (spot 4, Fig. 2 and Table 1), a zinc finger protein (spot 7, Fig. 2 and Table 1) and a Tyl regulation protein (spot 9, Fig. 2 and Table 1).

Another important question raised by the results is whether the proteins reported here are indeed secreted by fungi, given that no signal peptides were detected. In order to resolve this question, an in silico search for signal peptides was performed using BLAST, FASTA 3 and Signal P, focusing on sequences representing these discovered enzyme classes (see Supplementary Table S1, available with the online version of this paper). All enzymes identified, with the exception of glucosamine 6-phosphate $N$-acetyltransferase and $N$-acetyl-D-glucosamine kinase, have indeed been observed in fungal secretions, as further described in
Supplementary Table S1. The two exceptions, by contrast, have been detected by our group only in bacterial secretions. Reinforcing the data in the table, literature on fungal secretions supports our findings in M. anisopliae. For example, acetyltransferases have been observed in $S$. cerevisiae (Einerhand et al., 1991), lyases in Aspergillus niger (Jenkins et al., 1996), kinases in S. cerevisiae (Destruelle et al., 1994), amidohydrolase in Schizosaccharomyces pombe (Albrecht et al., 2000), a dehydrogenase in Candida albicans (Gil-Navarro et al., 1997) and a oxidoreductase in Neurospora crassa (Germann et al., 1988). Furthermore, proteolytic and chitinolytic enzymes have been identified in extracellular secretions of M. anisopliae (St Leger et al. 1996). In silico evaluations increased our knowledge of the proteins sequenced in our study, providing further support for the metabolic pathways proposed in Figs 3 and 4. Although other spots found in 2D gels showed similarities to common secreted proteins such as chitinases, proteinases and glucosidases (data not shown), due to low scores, these data were removed. Further analyses may, however, elucidate these specific classes.

In the last few years, gene expression data have been characterized for a number of biocontrol agents, as a step 
towards development of disease-resistant genetically modified crop plants. For example, genes coding for endochitinases from the mycoparasitic fungus $T$. harzianum have been inserted into tobacco and potato, inducing disease resistance (Lorito et al., 1998). High expression levels of the fungal genes were obtained from different plant tissues, without visible detrimental effects upon plant growth and development, and with resistance conferred against phytopathogens such as Alternaria alternata, Alternaria solani, Botrytis cinerea and R. solani (Lorito et al., 1998). Brunner et al. (2005) developed a genetically modified strain of Trichoderma atroviride (SJ3-4), expressing the A. niger glucose oxidase-encoding gene, GoxA, under the control of a homologous chitinase (nag1) promoter. The modification of this strain improved its capacity as a biocontrol agent, with a threefold increase in spore germination inhibition in $B$. cinerea, together with an increased overgrowth and lysis of the plant pathogens $R$. solani and Pythium ultimum (Brunner et al., 2005). These studies demonstrate the potential of heterologous genes encoding diverse protein products from fungal biocontrol agents. Candidate gene discovery therefore has promise in development of new disease- and pest-resistant engineered plants, as well as genetically modified biocontrol agents for improved efficiency of pest and pathogen control.

\section{Concluding remarks}

In summary, this report provides new information with respect to the use of entomopathogenic fungi in the biological control of insect pests. A hydrolytic enzymic arsenal was characterized in M. anisopliae strain CG34, active in colonization and predation of C. maculatus. Given the capacity of this strain in control of bruchids, the enzymes characterized in this study represent a potential resource for development of biotechnological tools for control of insect pests.

Enzyme characterization also contributed to a clarification of the physiology of nutritional uptake and ammonium metabolism in filamentous fungi, with today's literature focused only on mechanisms in yeasts and bacteria. Enzymes such as methionine gamma lyase and nitrite oxidoreductase are clear targets for genetic manipulation and may serve, in the near future, for development of new biocompounds active against $C$. maculatus, together with genetic modification of plants for increased resistance to bruchid pests.

\section{ACKNOWLEDGEMENTS}

The Fundacao Coordenacao de Aperfeicoamento de Pessoal de Nivel Superior (CAPES), Conselho Nacional de Desenvolvimento Cientifico e Tecnologico (CNPq), Fundação de Amparo à Pesquisa do Estado de Minas Gerais (FAPEMIG) and Universidade Católica de Brasília (UCB) supported this work. The authors thank Dr Carlos Bloch Jr and Dr Luciano Paulino Silva at Embrapa Recursos Genéticos e Biotecnologia for provision and coordination of mass spectrometry activities.

\section{REFERENCES}

Adane, K., Moore, D. \& Archer, S. A. (1996). Preliminary studies on the use of Beauveria bassiana to control Sitophilus zeamais (Coleoptera: Curculionidae) in the laboratory. J Stored Prod Res 32, 105-113.

Albrecht, E. B., Hunyady, A. B., Stark, G. R. \& Patterson, T. E. (2000). Mechanisms of sod2 gene amplification in Schizosaccharomyces pombe. Mol Cell Biol 11, 873-886.

Banks, I. R., Specht, C. A., Donlin, M. J., Gerik, K. J., Levitz, S. M. \& Lodge, J. K. (2005). A chitin synthase and its regulator protein are critical for chitosan production and growth of the fungal pathogen Cryptococcus neoformans. Eukaryot Cell 4, 1902-1912.

Becker, N. (1998). The use of Bacillus thuringiensis subsp. israelensis (Bti) against mosquitoes, with special emphasis on the ecological impact. Isr J Entomol 32, 63-69.

Bidochka, M. J. \& Khachatourians, G. G. (1994). Protein hydrolysis in grasshopper cuticles by entomopathogenic fungal extracellular proteases. J Invertebr Pathol 63, 7-13.

Bourassa, C., Vincent, C., Lomer, C. J., Borgemeister, C. \& Mauffette, Y. (2001). Effects of entomopathogenic Hyphomycetes against the larger grain borer, Prostephanus truncatus (Horn.) (Coleoptera: Bostrichidae), and its predator, Teretriosoma nigrescens Lewis (Coleoptera: Histeridae). J Invertebr Pathol 77, 75-77.

Bradford, M. M. (1976). A rapid and sensitive method for the quantization of microgram quantities of protein utilizing the principle of protein-dye binding. Anal Biochem 72, 248-254.

Brunner, K., Zeilinger, S., Ciliento, R., Woo, S. L., Lorito, M., Kubicek, C. P. \& Mach, R. L. (2005). Improvement of the fungal biocontrol agent Trichoderma atroviride to enhance both antagonism and induction of plant systemic disease resistance. Appl Environ Microbiol 71, 3959-3965.

Carberry, S., Neville, C. M., Kavanagh, K. A. \& Doyle, S. (2006). Analysis of major intracellular proteins of Aspergillus fumigatus by MALDI mass spectrometry: identification and characterization of an elongation factor $1 \mathrm{~B}$ protein with glutathione transferase activity. Biochem Biophys Res Commun 341, 1096-1104.

Cherry, A. J., Abalob, P. \& Hella, K. (2005). A laboratory assessment of the potential of different strains of the entomopathogenic fungi Beauveria bassiana (Balsamo) Vuillemin and Metarhizium anisopliae (Metschnikoff) to control Callosobruchus maculatus (F.) (Coleoptera: Bruchidae) in stored cowpea. J Stored Prod Res 41, 295-309.

Credland, P. F., Dick, K. M. \& Wright, A. W. (1986). Relationship between larval density, adult size and egg production in cowpea seed beetle, Callosobruchus maculatus. Ecol Entomol 11, 41-50.

Cronin, V. B., Maras, B., Barra, D. \& Doonan, S. (1991). The amino acid sequence of the aspartate aminotransferase from baker's yeast (Saccharomyces cerevisiae). Biochem J 277, 335-340.

Delincee, H., Villavicencio, A.-L. C. H. \& Mancini-Filho, J. (1998). Protein quality of irradiated Brazilian beans. Radiat Phys Chem 52, 43-47.

Destruelle, M., Holzer, H. \& Klionsky, D. J. (1994). Identification and characterization of a novel yeast gene: the YGP1 gene product is a highly glycosylated secreted protein that is synthesized in response to nutrient limitation. Mol Cell Biol 14, 2740-2754.

Einerhand, A. W., Voorn-Brouwer, T. M., Erdmann, R., Kunau, W. H. \& Tabak, H. F. (1991). Regulation of transcription of the gene coding for peroxisomal 3-oxoacyl-CoA thiolase of Saccharomyces cerevisiae. Eur J Biochem 200, 113-122.

Galvan, T. L., Koch, R. L. \& Hutchison, W. D. (2006). Toxicity of indoxacarb and spinosad to the multicolored Asian lady beetle, 
Harmonia axyridis (Coleoptera: Coccinellidae), via three routes of exposure. Pest Manag Sci 62, 797-804.

Germann, U. A., Müller, G., Hunziker, P. E. \& Lerch, K. (1988). Characterization of two allelic forms of Neurospora crassa laccase. Amino- and carboxyl-terminal processing of a precursor. J Biol Chem 263, 885-896.

Gil-Navarro, I., Gil, M. L., Casanova, M., O’Connor, J. E., Martínez, J. P. \& Gozalbo, D. (1997). The glycolytic enzyme glyceraldehyde-3phosphate dehydrogenase of Candida albicans is a surface antigen. $J$ Bacteriol 179, 4992-4999.

Gorg, A., Postel, W. \& Gunther, S. (1988). The current state of twodimensional electrophoresis with immobilized $\mathrm{pH}$ gradients. Electrophoresis 9, 531-546.

Grinyer, J., McKay, M., Nevalainen, H. \& Herbert, B. R. (2004). Fungal proteomics: initial mapping of biological control strain Trichoderma harzianum. Curr Genet 45, 163-169.

Grinyer, J., Hunt, S., McKay, M., Herbert, B. R. \& Nevalainen, H. (2005). Proteomic response of the biological control fungus Trichoderma atroviride to growth on the cell walls of Rhizoctonia solani. Curr Genet 47, 381-388.

Henzel, W. J., Billeci, T. M., Stults, J. T. \& Wong, S. C. (1993). Identifying proteins from two-dimensional gels by molecular mass searching of peptide fragments in protein sequence databases. Proc Natl Acad Sci U S A 90, 5011-5015.

Hess, D. C., Lu, W., Rabinowitz, J. D. \& Botstein, D. (2006). Ammonium toxicity and potassium limitation in yeast. PLoS Biol 4 doi:10.1371/journal.pbio.0040351.

Jackai, L. E. N. \& Adalla, C. B. (1997). Pest management practices in cowpea. In Advances in Cowpea Research, pp. 240-258. Edited by B. B. Singh, D. R. M. Raj, K. E. Dashiell \& L. E. N. Jackai. Ibadan, Nigeria: International Institute of Tropical Agriculture (IITA) and Japan International Research Center for Agricultural Sciences (JIRCAS).

Jenkins, J., Scott, M., Mayans, O., Pickersgill, R., Harris, G., Connerton, I. \& Gravesen, T. (1996). Crystallization and preliminary $\mathrm{X}$-ray analysis of pectin lyase A from Aspergillus niger. Acta Crystallogr D Biol Crystallogr 52, 402-404.

Kang, S. C., Park, S. \& Lee, D. G. (1999). Purification and characterization of a novel chitinase from the entomopathogenic fungus, Metarhizium anisopliae. J Invertebr Pathol 73, 276-281.

Kassa, A., Zimmermann, G., Stephan, D. \& Vidal, S. (2002). Susceptibility of Sitophilus zeamais (Motsch.) (Coleoptera: Curculionidae) and Prostephanus truncatus (Horn) (Coleoptera: Bostrichidae) to entomopathogenic fungi from Ethiopia. Biochem Sci Technol 12, 727-736.

Kaya, H. K. \& Gaugler, R. (1993). Entomopathogenic nematodes. Annu Rev Entomol 38, 181-206.

Kneip, C., Lockhart, P., Voß, C. \& Maier, U.-G. (2007). Nitrogen fixation in eukaryotes - new models for symbiosis. BMC Evol Biol 7, 55.

Kolkman, A., Daran-Lapujade, P., Fullaondo, A., Olsthoorn, M. M. A., Pronk, J T., Slijper, M. \& Heck, A. J. (2006). Proteome analysis of yeast response to various nutrient limitations. Mol Syst Biol May 2006 doi: $10.1038 / \mathrm{msb} 4100069$.

Laemmli, U. K. (1970). Cleavage of structural proteins during the assembly of the head of bacteriophage T4. Nature 227, 680-685.

Legner, E. F. (1995). Biological control of Diptera of medical and veterinary importance. J Vector Ecol 20, 59-120.

Lesage, G. \& Bussey, H. (2006). Cell wall assembly in Saccharomyces cerevisiae. Microbiol Mol Biol Rev 70, 317-343.
Lomako, J., Lomako, W. M. \& Whelan, W. J. (2004). Glycogenin: the primer for mammalian and yeast glycogen synthesis. Biochim Biophys Acta 1673, 45-55.

Lorito, M., Woo, S. L., Garcia, I., Colucci, G., Harman, G. E., PintorToro, J. A., Filippone, E., Muccifora, S., Lawrence, C. B. \& other authors (1998). Genes from mycoparasitic fungi as a source for improving plant resistance to fungal pathogens. Proc Natl Acad Sci U S A 95, 7860-7865.

Marzluf, G. A. (1981). Regulation of nitrogen metabolism and gene expression in fungi. Microbiol Rev 45, 437-461.

Murad, A. M., Laumann, R. A., Lima, Tde A., Sarmento, R. B. C., Noronha, E. F., Rocha, T. L., Valadares-Inglis, M. C. \& Franco, O. L. (2006). Screening of entomopathogenic Metarhizium anisopliae isolates and proteomic analysis of secretion synthesized in response to cowpea weevil (Callosobruchus maculatus) exoskeleton. Comp Biochem Physiol C Toxicol Pharmacol 142, 365-370.

Murad, A. M., Laumann, R. A., Mehta, A., Noronha, E. F. \& Franco, O. L. (2007). Screening and secretomic analysis of enthomopatogenic Beauveria bassiana isolates in response to cowpea weevil (Callosobruchus maculatus) exoskeleton. Comp Biochem Physiol C Toxicol Pharmacol 145, 333-338.

Nahar, P., Ghormade, V. \& Deshpande, M. V. (2004). The extracellular constitutive production of chitin deacetylase in Metarhizium anisopliae: possible edge to entomopathogenic fungi in the biological control of insect pests. J Invertebr Pathol 85, 80-88.

Rice, W. C. \& Cogburn, R. R. (1999). Activity of entomopathogenic fungus Beauveria bassiana (Deuteromycota: Hyphomycetes) against three coleopteran pests of stored grain. J Econ Entomol 92, 691-694.

Scholte, E. J., Knols, B. G. J., Samson, R. A. \& Takken, W. (2004). Entomopathogenic fungi for mosquito control. J Insect Sci 4, 19.

Shevchenko, A., Wilm, M., Vorm, O. \& Mann, M. (1996). Mass spectrometric sequencing of proteins from silver stained polyacrylamide gels. Anal Chem 68, 850-858.

Sorensen, T. K., Dyera, P. S., Fierro, F., Laube, U. \& Peberdy, J. F. (2003). Characterization of the gptA gene, encoding UDP $\mathrm{N}$ acetylglucosamine:dolichol phosphate $N$-acetylglucosaminylphosphoryl transferase, from the filamentous fungus, Aspergillus niger. Biochim Biophys Acta 1619, 89-97.

St Leger, R. J., Cooper, R. M. \& Charnley, A. K. (1986). Cuticle degrading enzymes of entomopathogenic fungi: regulation of production of chitinolytic enzymes. J Gen Microbiol 132, 1509-1517. St Leger, R. J., Charnley, A. K. \& Cooper, R. M. (1987). Characterization of cuticle-degrading proteases produced by the entomopathogen Metarhizium anisopliae. Arch Biochem Biophys 253, 221-232.

St Leger, R. J., Bidochka, M. J. \& Roberts, D. W. (1994). Isoforms of the cuticle-degrading Prl proteinase and production of a metalloproteinase by Metarhizium anisopliae. Arch Biochem Biophys 313, 1-7.

St Leger, R. J., Joshi, L., Bidochka, M. J., Rizzo, N. W. \& Roberts, D. W. (1996). Biochemical characterization and ultrastructural localization of two extracellular trypsins produced by Metarhizium anisopliae in infected insect cuticles. Appl Environ Microbiol 62, 1257-1264.

Suarez, M. B., Sanz, L., Chamorro, M. I., Rey, M., González, F. J., Llobell, A. \& Monte, E. (2005). Proteomic analysis of secreted proteins from Trichoderma harzianum: identification of a fungal cell wallinduced aspartic protease. Fungal Genet Biol 42, 924-934.

Edited by: B. A. Horwitz 